\title{
Grandparenting Style in Malaysia: Implication on Social Work Roles
}

\section{Alavi K., Doris Dagang, Norulhuda Sarnon@Kusenin}

To Link this Article: http://dx.doi.org/10.6007/IJARBSS/v11-i6/10223

DOI:10.6007/IJARBSS/v11-i6/10223

Received: 17 April 2021, Revised: 20 May 2021, Accepted: 02 June 2021

Published Online: 19 June 2021

In-Text Citation: (Alavi et al., 2021)

To Cite this Article: Alavi, K., Dagang, D., \& Sarnon@Kusenin, N. (2021). Grandparenting Style in Malaysia: Implication on Social Work Roles. International Journal of Academic Research in Business and Social Sciences, 11(6), 924-935.

\section{Copyright: @ 2021 The Author(s)}

Published by Human Resource Management Academic Research Society (www.hrmars.com)

This article is published under the Creative Commons Attribution (CC BY 4.0) license. Anyone may reproduce, distribute, translate and create derivative works of this article (for both commercial and non-commercial purposes), subject to full attribution to the original publication and authors. The full terms of this license may be seen at: http://creativecommons.org/licences/by/4.0/legalcode

\section{Vol. 11, No. 6, 2021, Pg. 924- 935}

Full Terms \& Conditions of access and use can be found at http://hrmars.com/index.php/pages/detail/publication-ethics 


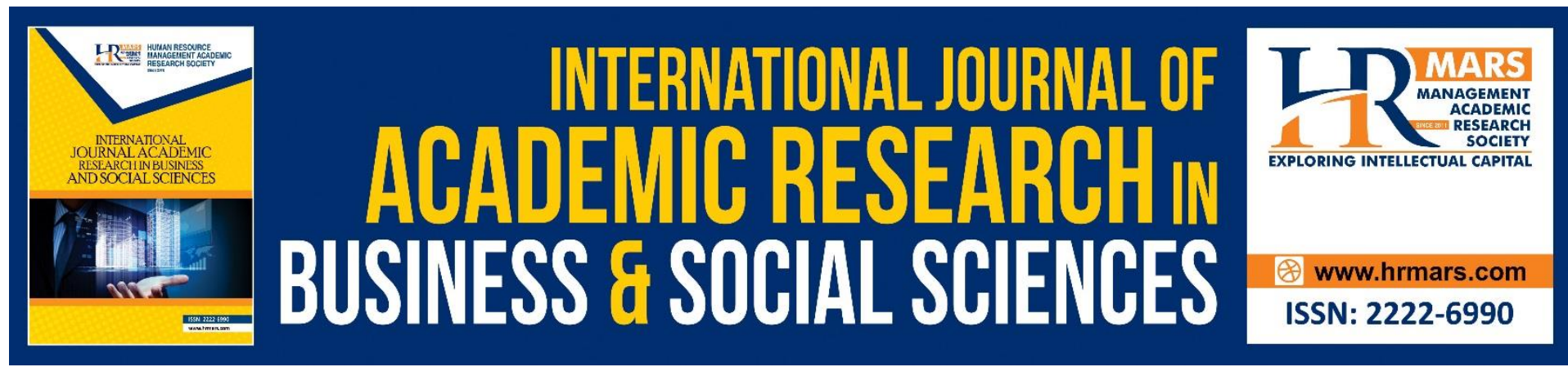

\title{
Grandparenting Style in Malaysia: Implication on Social Work Roles
}

\section{Alavi K., Doris Dagang, Norulhuda Sarnon@Kusenin}

Social Work Program, Centre for Research in Psychology and Human Well-Being Faculty of Social Sciences and Humanities, Universiti Kebangsaan Malaysia, 43600, Bangi, Selangor Email: khadijah@ukm.edu.my

\begin{abstract}
There has been an increase in grandparents raising their grandchildren resulting shift in their roles and parenting styles. This article explores grandparents parenting styles as alternative caregivers, in the development of the national family. The study used a qualitative approach based on case studies. A total of 23 respondents were successfully interviewed in detail and their answers were analysed thematically. The study found that most respondents use "Passive" style; six respondents exhibited "Surrogate" style, five respondents displayed "Authoritative" style and four respondents showed "Reservoir of Family Wisdom" style. Whereas, only two respondents used the "Fun-Seeker", and "Multi" style. The majority of respondents are taking care of their grandchildren full time. The implications from the study suggest that the role of social workers needs to be facilitator and collaboration to expand grandparents' potential in developing an upright family system. Social workers can help provide multiple strategies to ensure the grandparents-grandchildren relationship and subjective wellbeing. Future research avenues shed a light to empower grandparents' involvement in strengthening family system.
\end{abstract}

Keywords: Grandparenting Style, Grandchildren, Social Work, Role

\section{Introduction}

The sudden economic development is important factors that have an impact on grandparents raising their grandchildren. Several studies describe the demographic characteristics of grandparents as caregivers (Fuller-Thomson \& Driver, 1997; Szinovacz, 1999; Khadijah et al., 2016). However, not much research done to identify the shift is parenting roles assumed by grandparents who care for their grandchildren, in Malaysia. The findings also show that some grandparents are actively raising their grandchildren together with their parents (Szinovacz, 1999). Researcher found that often the caretaker role has been sudden and unwelcome (Jendrek, 1994). Some studies found that the frequency of grandparents caring for grandchildren has increased over the last few years and the reason grandparents living with grandchildren have also changed. In the modern era, the majority of mothers play a dual role: not merely focusing on family responsibilities like the olden days. Many working parents, who are busy, are faced with childcare problems (Suhana, 2000; Rahimah, 2007). Married women who continue to work, and send their children to be cared by grandparents, face another set 
of problems; children showing less affection to biological parents and custody. Children are left under the care of grandparents as their parents fail to handle them for the following reasons; divorced parents, teenage pregnancy, illegitimacy, drug addiction, conviction. Parents also tend to leave their children with grandparents on the grounds of seeking employment or continuing their education. Additionally, grandparent assumes the responsibilities of caring for their grandchildren in cases of parental loss linked to deadly diseases such as stroke, heart disease, diabetes, high blood pressure or in road accidents. This is known as "skip generation" as grandparents raise their grandchildren with no assistance from parents. The problem exists because they have no choice but assume the Caregiving roles. This is where the social worker involved to empower grandparents as family caregivers, is very much needed.

According to Pebley and Rudkin (1999), there are two main reasons to the current trends in grandparents raising grandchildren. First, most policy makers found that grandparents are safety nets to their grandchildren. Governments seemed to change the child care policies in troubled family, back to the family or community care, thus creating additional burden to grandparents (Mullen, 1996). Government policymakers are not in favour of using deinstitutionalisation approach as children growing up in orphanages or child care contested to be isolated from community, lack affection, involved in social problems and suffer psychological trauma. They often do not succeed in education and eventually become a burden to the county. Thus, empowering grandparents can enhance their potential as an alternative or in transit care provider to their grandchildren.

Second, the process of empowering of grandparents in raising grandchildren can improve intergenerational relationships in this millennium, and in future in Malaysia. Empowering grandparents bring different consequences on them as grandmothers tend to live longer than the grandfathers. Therefore, occupying a role in a longer period and may have a different impact on grandparents and grandchildren. Grandmothers are closer to their grandchildren, regardless of their gender. Grandfathers are closer to their grandsons. Maternal grandparents are closer to their grandchildren. During a family crisis, maternal grandparents are sought after more for help as they are more accommodating. Grandmothers are more contended in raising grandchildren compared to grandfathers, as they look upon as a second chance at parenting (Khadijah, 2012).

Grandparents are partly responsible for their grandchildren's or great-grandchild's development, and indirectly help ease the burden of their adult children in caring and upbringing, their children, especially for those living in cities and working full time. The roles of grandparents in parenting are beneficial and economical for the family, and help improve the quality of human capital. In fact, some grandparents did not expect to take up the parenting role in their advanced age. Their main challenge of parenting at a later stage is their health, time, financial constraints, and communication obstacles with grandchildren, limited socialization, and limited time for spiritual or religious activities. Grandparents who assume the role of parenting and caregiving in old age, usually lack resources and health alterations.

Grand parenting has been classified into five categories: namely formal; fun seeker; surrogate; a reservoir of family wisdom and distant figure. The role grandparents assume is greatly influenced by their age (Neugarten \& Weinstein, 1964). Grandparents who are 
categorized as fun seeker and distant figures are still young and active, usually 64 years and below. While formal grandparents are elderly and less active, normally 65 years of age or older. Generally more grandparents adapt to the formal and distant styles. The grandparent's informal parenting style is very loving in nature. Some studies have found that democratic parenting style is most favourable to childhood and youth development, and children brought up in this style are outstanding for their social competency, maturity, self-esteem and the ability to control themselves, and independence (Parke \& Buriel, 1998; Steinberg \& Silk, 2002; Saadah et al., 2021).

In Malaysia, the life expectancy of the elderly within the next 10 years will reach 70 years for men and 74 years for women. Thus, the number of elderly people aged 60 years and older will increase to 1529000 people (6.82 per cent) from the country's total population during the year 2000. Statistics for 2012 show that the elderly in Malaysia have reached 9.9 percent, which is about 2.7 million people. By 2020 the elderly population is estimated to increase to 12 percent or more, 3.4 million and is estimated to reach 15 percent or more by 2035 Department of Statistics, Malaysia $(2010 ; 2013)$. Government should plan to manage the increased population density of healthy elderly by channelling their energy optimally for family development. Therefore, the government should review grandparents' potential and empower them in raising young children and adolescents in educating, guiding, managing and protecting these children. This study will explore grand parenting styles among grandparents. To what extent empowerment should be given to grandparents in handling their new role as alternative custodians and to keep them active and productive.

\section{Objective}

The objective of the study is to explore grand parenting styles and social workers' role in enhancing their potentials as alternative custodian to their grandchildren in the national family development.

\section{Research Method \\ Research Design}

This research used an in-depth interviews and case study approach. This approach and method depicted the background of research subjects, mostly grandparents who were willing to share their experiences on empowerment and their potential of raising grandchildren. The subjects were chosen based on the criteria that they are actively taking care of their grandchildren.

\section{Research Sample}

The respondents were 23 grandparents of Malays, Chinese and Indians ethnicity, living in suburban of Selangor. An in - depth interview, qualitative in nature was conducted in an open and unstructured manner, to deduce "what are the style grandparents are using in providing care for their grandchildren during the last stage of their lives in a modern and challenging situation? ". Additional questions were asked about how to empower grandparents as a family caregiver to improve the quality of intellectual and social talents among the grandchildren. 


\section{Data Analysis}

The data were analysed using identified themes from grandparents. Coding (coding data) by labelling the key issues and established a pattern that emerge from thematic diagrams with the objectives. To study the differences and similarities of data according from the main issues, we use mapping and interpretation of data. The main focus of the research was to develop a thematic framework.

\section{Findings and Discussions}

Parenting style used by grandparents to raise their grandchildren is different from the style used on their own children. According to the first research conducted by Neugerten \& Weinstein (1964), there were two grand parenting styles; formal and informal style. A study conducted by Cherlin \& Furstein (1985) have identified five grand parenting styles; detached style, passive style, supportive style, authoritative style, and influential force. Furthermore, Neugarten \& Weinstein (1964) classified the following five grand parenting styles; formal, funseeker, surrogate, influential and reservoir of family wisdom. In this study, we used the Neugerten \& Weinstein (1964) propagated grand parenting styles. The results of this study found that grandparents have used 6 grand parenting styles in raising their grandchildren.

\section{Passive Style}

Grandparents who use the passive style are not so involved in parenting. They keep an eye on their grandchildren and advise them on appropriate behaviour and manners.

"It's not easy taking care of grandchildren. We don't have much say on someone's child, unlike our own children. When my kids were naughty I pinched them, but dare not touch my grandchildren if they are naughty. When I call them to eat, they won't come, so I leave it to them when they want to eat. They call me mom, not grandma, coz they have been with me since they were small. I just scold them, and never hit them, when they fight among siblings." (Respondent 3)

I simply look after them, and just advise not to get involved in bad behavior in school, to obey their teacher. And don't answer back to adults." (Respondent 13)

“.... My grandkids are not unruly. I just scold them when naughty, that's it. (Respondent 14)

"I don't beat or scold my grandchildren, just advise and warn them, so that they don't retaliate. Even when they are sick, I leave it to their parents to treat them." (Respondent 19)

"We take care of their basic needs; warn them not to be naughty. They go to school in the morning and will be back in the evening. I prepare meals for them. Then they go for tuition. Their parents will fetch them after dinner. I have some time with them on the days they don't go for tuition. We will watch TV and chit chat." (Respondent 20)

"We just take care, if they fall sick, will call their parents. No trouble to take care of them, just keep an eye on them. If they disobey I threaten to tell their father. They fear their father." (Respondent 21)

The six respondents explained that they are less involved in raising their grandchildren. They only look after the basic needs of their grandchildren. They leave it to parents to take charge 
in matters such as education, sustenance and health. Researchers found that all three Chinese respondents interviewed used "Passive" style in caring for their grandchildren.

\section{Surrogate Style}

Grandparents using "Surrogate" parenting style will act like parents to their grandchildren. They feel responsible and involve themselves to establish good behaviour in grandchildren. In addition, such grandparents educate their grandchildren emphasizing on mannerism. Grandparents of this type will reward their grandchildren who portray good behaviour and correct those who are rude or engage in inappropriate action. Surrogate grandparents will not punish, but they will reward with affirmation in guiding their grandchildren to accepted behaviour. Respondent 1 stated that they were strict in shaping the table manners of their grandchildren.

"I'm flexible ...coz his father is strict. His father doesn't like me controlling his child. If the kid is stubborn, and insist on doing what I refrain, I use diplomatic means of controlling his behavior. If he spills food while playing during dining, I will to feed him, although he may insist on eating by himself. Also, I will just put away the toys until he finishes eating." (Respondent 1)

Respondents 4, 5, 6 and 11 also shared their experiences of caring their grandchildren like their own children. Grandparents also feel that they spoil their grandchildren more, compared to their own children in those days. This is because; grandchildren are spending more time with their grandparents while their parents work from early morning until late evening. Thus, the grandparents shoulder all household responsibilities such as cooking, cleaning, in addition to being a custodian to their grandchildren.

"I'm doing all the household chores, as I'm staying at home. I don't expect others to do my household chores. When they come home from work, meals are ready. Not formal style, I follow my style and treat them like my own" (Respondent 4)

"Just give them a normal care, as they are my own grandchildren...just like taking care of my kids when they were small. Difficult to take care of small kids, nowadays, as they are very active and cannot control them. If they do wrong I will advise them, and teach them the right thing. We should shape their behavior from young, and makes it a habit. (Respondent 5)

"My grandchild is quite pampered. Every now and then he will call for me. I'm not that strict but they are obedient. I feel differently towards my grandchildren compared to my own children. I used to scold my children but don't have the heart to reprimand my grandchildren. If I do, it won't be a long lecture, they are close to me. If his mother scolds him, he will run to me, and hug me. Also, because I pamper him most. Although he is here almost the whole day, I can still carry on with my chores. (Respondent 6)

"We got to treat our grandchildren the way we treated our kids. If they are sick, I'll give them medicine, if they wrong, I'll give a piece of my mind. Yesterday he carelessly spilt a bowl of Maggimee (noodles), I did scold him for that. When I'm very angry, he is scared and obeys. My grandchild is my own flesh and blood, I have every right to advise him." (Respondent 11) 
The five respondents above use surrogate style in raising their grandchildren. Grandparents who care for their grandchildren bear all the responsibilities in taking care of them full time. The researchers suggest that grandparents should make to understand empowerment and changes in their potential. In power motivation, the grandparents have to get information about the changes, the environment, and must be willing to identify and work with others to change (Judith 2001; Cherlin \& Furstenberg 1985). The ability to understand the changes in themselves and the environment empowers the parenting knowledge. This means that grandparents will not feel trapped, manipulated or suppressed in passing traditional knowledge, cultural practices, and values to grandchildren.

\section{Authoritative Style}

Grandparents who use Authoritative style often act decisively against grandchildren. They use punishment to mould their grandchildren's behaviour or to portray the desired actions. Most grandchildren raised in this style, tend to obey the instructions given for fear of the punishments.

"It's really a challenge to attend grandchildren, especially when they fight. So much noise in the morning, I have to spare the rod. ... I'm a very strict granny and they can't play a fool with me. They fear their dad too. When I get mad I hit them, then feel sorry to see them in pain." (Respondent 7)

"I'm quite firm, and hit them if they don't obey. I lose my temper too. They pay less attention to advices. If they do wrong, I scold them, pull their ears, or threaten to tell their dad. They fear their dad will cane them." (Respondent 10)

"Kids in those days were not as difficult as the kids nowadays. I beat, I cane, they are scared the moment I raise my hand. Have to be strict with them. They do play tricks on me, hid in the cupboard for 2 hours. They fear me coz I'm very strict. They do complain about me to their mom, that I scold them" (Respondent 16)

"These days not much can be said to grandkids. It was easier to take care of kids in the past. We were able to sit and enjoy our drinks, while they have their milk. But now, they will be climbing up and down. I can't be telling them many times, so I resort to hitting. Their mom gave her consent to beat if they are naughty. When advising they will listen for 5mins and start the fight again." (Respondent 17)

All the above respondents preferred the "authoritative" type of parenting, very strict in controlling grandchildren's behaviour. Respondent $7,10,16,17$, is dealing with unruly grandchildren and find it difficult to control their behaviour. In this case some kind of corporal punishment is resorted to control grandchildren's behaviour. Almost all respondents said, they have difficulties caring for their grandchildren now, compared to raising their children in the past.

\section{Reservoir of Family Wisdom Style}

Grandparents who use this style are often a source of inspiration to their grandchildren as they share and advice based on their past experiences. They expect their grandchildren to 
abide by the family tradition. Two respondents from this study are upholding this style while raising their grandchildren.

"I tell them our family history, share our experiences, and advise them accordingly. ... They are closer to grandma. They admit to any wrongdoing, they have done and listen to my advice." (Respondent 8)

"I like giving advice. I create my own story as lessons. He likes fairy tales, from there I'll advise him, and he appreciates. He is not scared of me, as I'm not fierce. At times, when I scold him, he laughs, in the end no scolding." (Respondent 9)

"It's hard work to take care of grandchildren. I may scold my children, but dare not scold or punish my grandchildren. I like to tell stories to them, about family trees. We play together, dance, sing, and do many other activities together. One of my grandchildren is hyperactive, and doesn't listen to me. I leave it to the parents to discipline him." (Respondent 22)

"I teach my grandchildren what is expected of them from young. Even my children, abide by my rules. They will put away their toys after playing and tidy the living room after that. I appreciate they carry on with our family traditions." (Respondent 23)

The response given by the four respondent's show that they like telling stories and their life experiences to their grandchildren as a means of guiding them. Grandparents use this style to pass on family traits and values to the next generations.

\section{Fun-Seeker Style}

Grandparents who use "fun-seeker" style, like to play and joke with their grandchildren. They treat them like friends, thus overcoming their boredom. Grandparents will be happy when their grandchildren happy.

"Since he is still small...he relies on us for feeding ... and likes to amuse us. He is my companion, I don't feel lonely. As he is small, I just feed him milk, give food, play, and take him for a walk to visit our neighbors." (Respondent 2)

"Kids like to play. They are stubborn at times and not scared of anyone. He picks up fast what we say. Speaks English with his father. He wants everything to be fast and adamant about what he wants. He made his grandfather buy him an Ultraman Robot. (Respondent 12)

The respondents above treat their grandchild as a playmate where they spend the time to joke and play with them. They will be happy to see the grandchildren cheerful and often buy toys for the grandchildren.

\section{Multi-style Grand Parenting}

From this research, we found that some grandparents use multi style parenting in raising their grandchildren. They use more than one style of parenting. 
"At times I'm strict, and at times I show affection. I treat them just like treating my own kids. I punish them gently, like putting their hands. They look for me at bedtime, to sing and share stories. (Respondent 15)

Researchers found that the 15th respondent have used three grand parenting styles; surrogate, authoritative and playmate in raising her grandchildren. Grandparents undertake raising responsibilities as parents to their grandchildren. Therefore, grandchildren are closer and more affectionate to their grandparents than their own parents. These grandparents also use authoritative style to discipline their grandchildren. However, at times they treat their grandchildren as playmates and often joke with them.

"Having these kids are tough, unlike raising my four children. Nowadays kids are naughty, and cannot be scolded. They will go home and complain to their father. They don't fear me and listen to my advice. I don't interfere when they quarrel or fight. Their parents may not like us scolding their kids. Not easy to advise them. They look for me most of the time." (Respondent 18)

The explanation given by 18th respondent indicated that grandparents use the "Surrogate" and "passive" style in bringing up their grandchildren. The 18th respondent stated that she took up the responsibilities as parents to her grandchildren. Grandparents look after their grandchildren by providing food and accommodation, in addition to their household chores. The 18th respondent was parenting her grandchild just like mother parenting her child. In addition, the 18th respondents explained that she uses "passive" style parenting, by not getting involved so much with her grandchildren's behaviour. Whatever it is they are closer to her than their parents. One of the parenting styles used in this study is the "passive" style. This style is most often used by grandparents in taking care of grandchildren. Many grandparents who look after their grandchildren choose to observe their behaviour and stay away from being so involved in their grandchildren's activities. Due to age factor, grandparents' physical movements are inhibited for rigorous activities with grandchildren. Therefore, they prefer to just sit and watch their active grandchildren. In case of emergencies, the grandparents will contact the parents for further action. For example, when a grandchild is sick, grandparents will call and request the parents to take the child to the clinic. Such grandparents do not take charge in providing food, health care, or education for their grandchildren. Many Chinese grandparents adopting the passive style, have clear cut duties between them and their children in parenting roles.

Next popular style is the "surrogate" style. Many grandparents who take over the task of looking after their grandchildren will act as parents to grandchildren. They take charge to mould their grandchildren's behaviour, give encouragement and social support, and provide other necessities. Grandparents use rewards and punishments in moulding their grandchildren's behaviour. This style makes the grandchildren mindful to their grandparents' advice. There are grandparents who use the "Authoritative" style in looking after their grandchildren. However, this style is less popular than the "passive" and "surrogate" style. This is because grandparents are aware that their grandchildren are not in favour of the "Authoritative" style. "Authoritative" style grandparents are strict, bossy, reluctant to accept the views or opinions of grandchildren, difficult to hold discussions with, expects submissive grandchildren and use corporal punishments as a means to educate them. Grandparents who 
use this style will not give much freedom to the grandchildren under their care. Grandchildren may find themselves restricted by grandparents. Usually grandparents use this style when they take care for many grandchildren. This style results in obedient and submissive grandchildren. However, this style discourages the grandchildren from speaking up and inhibits their creativity. In addition, grandparents from this study also use the "reservoir of family wisdom" style. Grandparents who use this style prefer to talk about family stories, family traditions and stories of the past that can be used as a living example. Grandparents would prefer their grandchildren to keep up with the family tradition. Grandparents are perceived as family historians whose storytelling skills can attract grandchildren's curiosity and interest. Grandchildren will grow as smart thinkers, attentive listeners and curious interrogator.

Other than that, some grandparents use "fun - seeker" style of grand parenting to look after their grandchildren. However, this style is less popular compared to the other four styles, namely; "passive ", "Surrogate", "Authoritative ", and "reservoir of family wisdom". Grandparents who apply the fun-seeker style enjoy the time they spend with their grandchildren. They treat their grandchildren as their playmates. The fun-seeker types of grand parenting are mostly used by grandparents who voluntarily care for their grandchildren. These grandparents appreciate living with their grandchildren as they break their boredom and loneliness. The study found that there are grandparents who use "multi style" parenting, which is a combination of several grand parenting styles. Grandparents who care for grandchildren using this style are not confined to use a particular style, rather they apply the style that best suits the situation. The results show that most grandparents combine the "Surrogate" and "passive" style. Grandparents of this type will take full responsibility in raising their grandchildren. However, there are times when grandparents just keep an eye on their grandchildren, and don't get involved in sibling fights or quarrels. Often, parents do not like their children to be disciplined by others, including grandparents. Grandparents are more comfortable to stay away from reprimanding their grandchildren, to avoid any family conflict when they act upon them.

\section{Conclusion and Suggestions}

Changes in society and government policies today have created more employment for women. Many women have chosen to pursue their career, leaving behind the traditional roles of managing their home. Thus, their children are placed under the care of grandparents. In addition, grandparents take care of grandchildren for the following reasons too; safety of grandchildren, family finances, young parents pursuing their education, hobbies and interests, and grandchildren with disabilities. The study found that most respondents use "Passive "style in providing care for their grandchildren, a total of 6 respondents. Then followed by "Surrogate" style; 5 respondents, "Authoritative" style and "Reservoir of Family Wisdom" style of 4 respondents. While the "Fun - Seeker" style, and the diversity of lifestyles (multi- style) 2 respondents respectively.

Grandparents need social workers' services to empower them to enhance the functionality of a harmonious family (Norulhuda Sarnon et al. 2021). Social workers need to get more exposure and understanding on the role of grandparents in family advancements and help strengthen the quality of family wellbeing and child development. Social workers can help their clients identify grand parenting ideals, realize their hopes and dream, understand their 
potential and their environment. Social workers can play the role of facilitators or collaborators in improving the ability of grandparents to act on the issues of grandchildren caregiving. Typically, social workers will not attend to caregiving issues of grandchildren specifically unless there are cases of neglect and abuse reported. However, social workers in Malaysia also play a role in overseeing the caregiving style of grandparents to improve the well-being of family members, especially the grandchildren being cared for. For grandparents who choose a passive style, they could not perform many activities due to physical limitations. Nevertheless, they can be assisted to not only become the observer but also play the role of good listeners for their grandchildren and as the mediator by pointing out their grandchildren's risky behavior to their children or social workers such as teenagers found smoking cigarettes in their room when their parents are absent. Social workers can help provide confidence and reassurance that the grandparents-grandchildren relationship will not be affected by passing on risky information to their children. The Surrogate style, there are times where this role causes stress to the grandparents due to their challenging role. Moreover, this style might cause their children to become less skilled in becoming a parent. Therefore, social workers can become the mediator by balancing the role played by the grandparents or their children as parents. Although sometimes the children have no choice and had to leave the grandchildren to their grandparents due to work, social workers can still balance it out by having family conference to achieve an agreement together in the role distribution. This is to lessen the family's dependency on the grandparents.

Alternatively, in managing grandparents with authoritative style, the advocator role can be played by giving knowledge to the grandparents about the risks of using too much power on their grandchildren. Social workers can play a part of becoming an educator to educate the grandchildren about their grandparent's authoritative style is due to their intention and hopes of the best for their grandchildren, and it does not mean they do not love their grandchildren. Grandparents who chose "Reservoir of Family Wisdom" and "Fun - Seeker" style of grand parenting, the role played as grandparents are the role that is always giving harmony. Social workers can play a role as empower to maintain the family's harmony and using this source as a family's strength to care for each other. This style of grand parenting also eases family activities planned and executed with harmony. Furthermore, for grandparents that uses multi-style grand parenting, more thorough assessments is required to observe whichever grand parenting styles dominated being used. Social workers have to match the situation and suitability of grand parenting style used in certain situations and the grandparents' physical ability.

Research suggests that grandparents attend modular training programs on grand parenting that promotes "Reservoir of Family Wisdom" and "Fun-Seeker" style, conducted through a communal social work in order to improve the quality of family development. Further studies can be extended to survey forms, to design a better generalization on grand parenting and challenges faced by social workers in empowering grandparents who care for their grandchildren. This study should also be extended to the entire country. Longitudinal design studies should also be carried out to see the trend in grand parenting styles to help improve the quality of human capital of grandchildren and productive aging among grandparents. 


\section{Reference}

Cherlin, A., \& Furstenberg, F. F. (1985). Styles and strategies of grand parenting. In V. L.

Department of Statistics, Malaysia (2010). Population Projection, Malaysia 2001-2020. Putrajaya: Department of Statistics Malaysia.

Department of Statistics, Malaysia (2013). Demography Indicator. Putrajaya: Department of Statistics Malaysia.

Fuller-Thomson, E., Minkler, M., \& Driver, D. (1997). A profile of grandparents raising grandchildren in the United States. The Gerontologist, 37, 406-411.

Jendrek, M. P. (1994). Grandparents who parent their grandchildren: Circumstances and decisions. The Gerontologist, 34, 206-216.

Judith, L. (2001). The empowerment approach to social work practice: Building the beloved community. ( $2^{\text {nd }}$ eds). Colombia University Press: New York, USM.

Khadijah A. (2012). Dilema Penjagaan Ibu Bapa Tua. Penerbit UKM: Bangi, Selangor

Khadijah A., Doris, D., \& Jamiah, M. (2016). Grandparents raising grandchildren: Contributing factors and challenges in caregiving. E-Bangi Journal, Universiti Kebangsaan Malaysia. Vol. 11 (1):

McClelland, D. C. (1975). Power: The inner experience. New York: Irvington Press.

Mullen, F. (1996). Public benefits: Grandparents, grandchildren and welfare reform. Generation, 20 (1): 61-64. 125-136.

Neugarten, B., \& Weinstein, K. (1964). The changing American grandparent: Journal of Marriage and the Family, 26: 199-204.

Nur Saadah, M. A., \& Noremy, M. A. (2021). Empowering Informal Caregivers and Care for Family. - International Journal of Academic Research in Business and Social Sciences. 444-452.

Norulhuda, S., Sofia, A., Jana, N. S., Khadijah, A., \& Suhaimi, M. (2021). Challenges of Social Work Student Conducts A Practice on Family in Context of Relationship of Social Worker and Client. - International Journal of Academic Research in Progressive Education and Development. 629-641.

Parke, R. D., \& Buriel, R. (1998). Socialization in the family: Ethnic and ecological perspectives. In N. Eisenberg (Ed.) \& W. Damon (Series Ed.), Handbook of child psychology: Vol. 3, Social, emotional, and personality development (5th ed., pp. 463552). New York: John Wiley..

Pebley, A. R., \& Rudkin, L. L. (1999). Grandparents raising grandchildren: What do we know? Journal of Family Issues, 20, 218-242.

Pruchno, R. (1999). Raising grandchildren: The experience of Black and White grandmothers. The Gerontologist, 39, 209-221.

Rahimah, A. Z. (2007). Grandparenting: Issues and challenges. Akademika Journal UKM. Vol. 70: $103-115$.

Steinberg, L., \& Silk, X. (2002). Parenting adolescents. In Bornstein, M. H. (ed.), Handbook of Parenting: Vol. 1: Children and Parenting, Erlbaum, Mahwah, NJ, pp. 103-133.

Suhana, S. (2000). Warga tua: Isu dan fenomena dalam konsep jiran pengaruh dalam konteks penjagaan wargatua Bandar. Dalam Warga tua isu dan fenomena. Abdul Aziz Jemain, Rahimah Abdul Aziz danLukman Z. Mohamad. Bangi: Penerbit UKM.

Szinovacz, M. E. (1999). Grandparents today: A demographic profile. The Gerontologist, 38(1), 37-52. 